\title{
OVLASTI I MJERE ŽUPANIJSKIH I GRADSKIH VLASTI U JAVNOM ZDRAVSTVU U SLAVONIJI U 19. STOLJEĆU
}

\author{
Prof. dr. sc. Miro Gardaš* \\ Slavko Čandrlić, mag. iur.** \\ Marko Repic***
}

\author{
UDK: 614.258(497.5-35Osijek)“"18“ \\ https://doi.org/10.30925/zpfsr.41.2.5 \\ Ur.: 14. veljače 2020. \\ Pr.: 26. lipnja 2020. \\ Pregledni rad
}

\begin{abstract}
Sažetak
Tijekom 19. stoljeća u Slavoniji je neprekidno postojala opasnost od izbijanja epidemija zaraznih bolesti. Stoga su županijske i gradske vlasti imale dužnost brinuti se o poduzimanju mjera za njihovo sprječavanje. Skrbile su o provođenju naputaka koje su im slale središnje državne vlasti. Brojni akti sačuvani su u arhivskoj građi raznih fondova u Državnom arhivu u Osijeku. Početkom 19. stoljeća Osijek je dobio status slobodnoga kraljevskog grada čime je u njegovu nadležnost došlo provođenje mjera za sprječavanje epidemija za što su u gradskoj upravi ustrojena posebna tijela. Nakon ukidanja feudalizma, a osobito u vrijeme bana Ivana Mažuranića, pristupa se zamašnim reformama sustava javnog zdravstva. Donosi se Zakon o javnom zdravstvu 1874. i niz pratećih propisa koji su se bavili tom problematikom. Novi se zakon donosi 1894. te unosi određene novine, radi usklađivanja sa novim teritorijalnim ustrojem. Tako uređeno zdravstvo pružilo je dobar okvir za učinkovitu zdravstvenu zaštitu stanovništva i prevenciju izbijanja epidemija.
\end{abstract}

Ključne riječi: povijest; pravo; Slavonija; 19. stoljeće; javno zdravstvo.

\section{1. $U V O D$}

Jedna od temeljnih odlika života u zajednici je briga o javnom zdravstvu. Ljudi su rano uvidjeli da zajednički život ljudi na malom prostoru donosi puno rizika za zdravlje, pa čak i opstanak zajednice. Takav život neminovno vodi prihvaćenim rizicima od izbijanja bolesti i epidemija i zato je bilo nužno ustaliti određene obrasce ponašanja koji su te rizike smanjivali.

Zarazne su bolesti ostavile brojne tragove u čovjekovom djelovanju. Smrti

* Dr. sc. Miro Gardaš, redoviti profesor, Pravni fakultet Sveučilišta Josip Juraj Strossmayer u Osijeku; mgardas@pravos.hr.

** Slavko Čandrlić, mag. iur., doktorand, Pravni fakultet Sveučilišta Josip Juraj Strossmayer u Osijeku; slavko.candrlic@fdmz.hr.

*** Marko Repić, student, Pravni fakultet Sveučilišta Josip Juraj Strossmayer u Osijeku; mrepic@ hotmail.com. 
izazvane zaraznim bolestima prouzročile su prekid razvitka pojedinih gradova i demografske posljedice po stanovništvo krajeva koje su pogodile. Strah od zaraznih bolesti i borba protiv njih izazvali su brojne ljudske reakcije na ekonomskom, društvenom, zakonskom polju, pa čak i na polju umjetnosti i arhitekture.

Brojne su bolesti napadale čovjeka: lepra, tifus, dizenterija, sifilis, tuberkuloza, malarija, velike boginje, ali dvije od njih su svakako ostavile najvećeg traga i izazivale najveći strah - kuga i kolera. ${ }^{1}$

O epidemijama bolesti u povijesti različitih naroda možemo pronaći podatke u brojnim djelima - od zapisa u Bibliji o drevnim pošastima kao i vijesti brojnih grčkih i rimskih povjesničara.

Upravo zato, vrlo rano, već u prvim zakonskim tekstovima nalazimo odredbe kako postupati u određenim situacijama da bi se izbjegle opasnosti za zajednicu od mogućih zaraza i epidemija. Već su u nekim pretpovijesnim kulturama ukopi obavljani izvan granica naselja, a Grci i Rimljani su samo iznimno dopuštali ukop unutar gradskih zidina. Primjer tomu su nekropole u brojnim rimskim gradovima koje su se nalazile izvan gradskih zidina uz prometnice koje su vodile u gradove. ${ }^{2}$

No, zbog veličine carstva, žive trgovine s okolnim plemenima i čestih provala barbarskih plemena preko limesa - granice, epidemije zaraznih bolesti, a osobito kuge, katkad su uspjele prodrijeti u njega. Manjih je epidemija sigurno bilo više, a osobito su traga ostavile, tzv. „Galenova kuga” u drugoj polovini 2. stoljeća u kojoj je, između ostalih, stradao i rimski car Marko Aurelije te, tzv. „Ciprijanova kuga" iz druge polovine 3. stoljeća. Ciprijanova kuga je osobito bila pogubna, pa su pojedini dijelovi Rimskog Carstva ostali gotovo bez stanovništva. ${ }^{3}$

Takva je praksa postojala i u srednjem vijeku pa je poznat čitav niz nekropola uz izdvojene crkvene i samostanske komplekse. No razlog za to pritom je više bio povezan sa vjerskim razlozima, odnosno željom da se ukop obavi u blizini groba mučenika ili vjerskog simbola, negoli sa brigom o javnom zdravlju. No, i ukopi u srednjovjekovnim gradovima također su se obavljali izvan gradskih zidina, osobito jer su vladale česte epidemije zaraznih bolesti. ${ }^{4}$

U srednjovjekovnom razdoblju zabilježeno je više epidemija kuge, a najznamenitija, koja je gotovo postala sinonim za ovu bolest je, tzv. „Crna smrt”, epidemija koja je Europom vladala od 1348. pa do 1361. Ova je epidemija prepolovila europsko stanovništvo, a u nekim je krajevima smrtnost bila 90 \%. Posljedice su za ekonomski i društveni razvitak europskih zemalja bile ogromne i u nekim slučajevima teško nadoknadive. ${ }^{5}$

Ova epidemija kuga je, kao i druge koje su slijedile, pogodila i naše krajeve.

1 Vidi Mirko Dražen Grmek, Bolesti u osvit zapadne civilizacije, (Zagreb, Globus, 1989.)

2 Hermina Goricke-Lukić, Nekropole rimsko dobne Murse, (Osijek, Muzej Slavonije, 2011.) i

Zoran Wiewegh, Jugoistočna nekropola Siscije, (Sisak, Gradski muzej Sisak, 2003.)

3 Nikolaj A. Maškin, Istorija starog Rima, Beograd, (IDP Naučna KMD, 2005.), 403. i Ivan, Rabar, Poviest carstva rimskoga, (Zagreb, Naklada Matice hrvatske, 1888.), 251.

4 Jacques Le Goff, Civilizacija srednjovjekovnog zapada, (Zagreb, Golden Marketing, 1998.), 324-327.

5 Barbara Tuchman, Daleko zrcalo, zlosretno XIV stoljeće, (Zagreb, Grafički zavod Hrvatske, 1984.). 
Tako tijekom 14. i 15. stoljeća brojne epidemije pogađaju Zadar, Split, Šibenik i Rijeku. Dubrovnik tako još od 1377. uvodi instituciju karantene, odredivši da posade i roba koji dolaze iz krajeva koji su potencijalno bili opasni za zarazu bolešću moraju provesti mjesec dana u izolaciji na obližnjim otocima Supetru, Mrkanu ili Bobari. ${ }^{6}$

Nužno je napomenuti da su primorski gradovi koji su bili uvelike orijentirani na trgovinu sa stranim zemljama bili izloženi povećanom riziku od prodora epidemija zaraznih bolesti preko putnika i robe iz tih zemalja, a to je moglo ugroziti ekonomski boljitak i napredak tih gradova.

Upravo se zato u statutima dalmatinskih gradova pojavljuju i odredbe koje govore o sanitarnim mjerama koje treba poduzimati (zabrana bacanja smeća, održavanje čistoće ulica, zabrana držanja stoke u gradu i sl.). To su zapravo bili prvi početci pravnog reguliranja javnoga zdravstva na našim prostorima. ${ }^{7}$

\section{STANJE U JAVNOM ZDRAVSTVU U SLAVONIJI U 18. STOLJEĆU}

Niti u novovjekovnom razdoblju stanje u europskim gradovima nije bilo bolje. Velika napučenost, nerodne godine i siromaštvo prouzročili su česte epidemije mnogih bolesti; kuge, kolere, boginja, tifusa, malarije, tuberkuloze, difterije, sifilisa i mnogih drugih koje su prouzročile velike pomore stanovništva. ${ }^{8}$

Nakon oslobođenja Slavonije od Turaka krajem 17. stoljeća na tom je području postojala vojna uprava. Zloupotrebe vojnih zapovjednika bile su česte, stanovništvo je bježalo preko Save u Bosnu pod turskom vlašću, a brizi o javnom zdravlju posvećivalo se malo pažnje.

Situacija je bila vrlo teška. Liječnika gotovo da nije bilo, a liječničku pomoć stanovništvu pružali su uglavnom franjevački i isusovački redovnici, liječnici u samostanima. ${ }^{9}$ O teškom stanju svjedoči i podatak da je 1748. ljekarna pri franjevačkom samostanu u Virovitici počela dobivati novčanu pomoć od Virovitičke županije. U obrazloženju je navedeno da na području Virovitičke županije od Osijeka do Koprivnice nema niti jednoga drugog liječnika ili ljekarne. ${ }^{10}$

$\mathrm{U}$ to je vrijeme u Osijeku bila stacionirana jaka vojna posada pa je tako i znatan broj vojnih liječnika brinuo o zdravlju vojske. Oni su vjerojatno pomagali i malobrojnom civilnom stanovništvu.

Liječničku praksu obavljali su i ranarnici i brijači koji su radili i manje kirurške

6 Tatjana Buklijaš, „Kuga: nastajanje identiteta bolesti“, Hrvatska revija, br 2 (2002.): 5

7 Marinko Učur, Željko Bartulović, Zaštita od „pošasti“ u hrvatskoj povijesti u 18. i 19. stoljeću i nomotehničke pretpostavke za izradu propisa de lege ferenda, Zbornik radova sa III međunarodnog naučnog skupa Katastrofe prevencija i saniranje posljedica, ur. Mirko Kulić, (Brčko, Evropski univerzitet, Brčko, 2015.): 522.

8 Fernand Braudel, Strukture svakidašnjice, Materijalna civilizacija, ekonomija i kapitalizam od XV. do XIII. stoljeća, (Zagreb, August Cesarec, 1992.), 73.-85.

9 Friedrich Wilhelm von Taube, Slavonija i Srijem.1777.-1778., (Osijek, Državni arhiv u Osijeku, 2012.), 168.

10 Robert Skenderović, „Zdravstvene reforme Marije Terezije u Slavonskom provincijalu i Generale normativum sanitatis iz 1770.“, Scrinia slavonica, br. 5, (2005.): 115-143. 
zahvate. Liječničkom praksom bavili su se i kirurzi obrtnici koji su u Slavoniju uglavnom dolazili s vojskom. Kirurškim obrtom nastavili su se baviti i nakon razvojačenja, pa su tako u osječkoj Tvrđi djelovala dva, u Gornjem gradu dva, a u Donjem gradu jedan kirurg obrtnik. ${ }^{11}$

Tek dolaskom na vlast carice i kraljice Marije Terezije može se govoriti o velikim promjenama u civilnom životu i brizi o javnom zdravstvu na području Slavonije. Naime, Marija Terezija provela je velike reforme i u Slavoniji je uvela građansku vlast. Dokinula je dotadašnju vojnu upravu i ustrojila županije. Iako je velik dio Slavonije ostao izdvojen iz županijskog sustava i uključen u sastav Vojne granice, zloupotrebama vojske ipak u najvećoj mjeri dolazi kraj i uvodi se red u gotovo sve segmente života.

U svom reformatorskom radu vladarica se dotaknula i pitanja javnoga zdravstva. Prema njezinim je naredbama donesen Generale Normativum Sanitatis, 1770. Ovaj je propis obuhvatio niz zdravstvenih odredbi koje su donosili prijašnji vladari i temeljni je zdravstveni propis za čitavu carevinu.

Njime je predviđeno osnivanje sanitarnih komisija koje su trebale biti sastavljene od stručnog osoblja i koje bi po potrebi obavještavale Dvorsku sanitarnu komisiju u Beču o svojim odlukama. Već postojeće sanitarne komisije sa sjedištima u Osijeku, Zagrebu i Karlovcu uklopile su se u plan zamišljen ovim propisom.

Zakon se ponajviše bavio pitanjima djelovanja sanitarnih kordona te nam tako pokazuje brigu vlasti da zaraze ne prodiru u Monarhiju. No, zakon je propisao i obvezatno školovanje za sve osobe koje se bave medicinskom praksom; liječnike, ranarnike, apotekare, kupališne liječnike i babice. ${ }^{12}$

Generale Normativum Sanitatis na jednom je mjestu obuhvatio različite zdravstvene propise te u jasnom i preciznom obliku uredio više pitanja javnog zdravstva.

\section{STANJE U JAVNOM ZDRAVSTVU U OSIJEKU I SLAVONIJI U PRVOJ POLOVICI 19. STOLJEĆA}

Dobivanjem statusa slobodnog kraljevskog grada 1809. u nadležnost grada Osijeka prelaze i određene ovlasti u provođenju mjera centralnih državnih vlasti u brizi o javnom zdravstvu. Zanimljivo je da je upravo velika pomoć građana Osijeka pri gradnji kontumaca i držanje straže tijekom epidemije kuge u Srijemu od 1795. do 1796., u darovnici cara Franje I., navedena kao jedan od razloga za dodjelu toga statusa. ${ }^{13}$ Tako je grad Osijek postao nadležan o brizi o javnom zdravstvu na području grada i poduzimanju niza mjera i aktivnosti.

Već su 31. kolovoza 1809. na sastanku Gradskog poglavarstva imenovani i najvažniji gradski službenici, a među njima je bio gradski liječnik, kirurg i gradska

11 Skenderović, „Zdravstvene reforme Marije Terezije u Slavonskom provincijalu i Generale normativum sanitatis iz 1770.“, 120.

12 Skenderović, „Zdravstvene reforme Marije Terezije u Slavonskom provincijalu i Generale normativum sanitatis iz 1770.“, 140.

13 Stjepan Sršan, Slobodni i kraljevski grad Osijek 1809., (Osijek, Državni arhiv, 2009.), 51. 
primalja. ${ }^{14} \mathrm{U}$ arhivskoj građi fonda Poglavarstvo slobodnog kraljevskog grada Osijeka nalazimo na velik broj okružnica koje su državne vlasti prosljeđivale poglavarstvima gradova na području Carevine. Okružnicama su upućivali niže instance kako treba postupiti u slučaju opasnosti za pučanstvo, koje mjere trebaju poduzimati gradske vlasti u slučaju izbijanja epidemije ili opasnosti od nje. ${ }^{15}$

Naime tijekom 18. i 19. stoljeća u Habsburškoj monarhiji, a osobito u pograničnim krajevima u koje je pripadala i Slavonija postojala je velika opasnost od izbijanja epidemija. U arhivskoj građi Poglavarstva evidentna je znatna briga državne vlasti da se to spriječi. Osobitu opasnost predstavljala je mogućnost izbijanja epidemije kuge, kolere i tifusa. To se nekoliko puta i događalo i prouzročilo je velik broj smrtnih slučajeva i velike poremećaje u svakodnevnom životu.

Zanimljiv izvještaj o sustavu i provođenju kontumaca, ali i razmatranja o uzroku i širenju kuge, svojstvena razvitku medicine u 18. stoljeću, nalazimo u opisu Slavonije i Srijema F. W. von Taubea. ${ }^{16}$ Mnoga od tih saznanja nama su danas zastarjela, pa čak i smiješna, ali pokazuju nam veliko zanimanje i brigu kako vlasti, tako i javnosti o svemu što je povezano $s$ tom opasnom pošasti. ${ }^{17}$

Manje epidemije i sporadične pojave zaraznih bolesti bile su vrlo česte, a osobito je kobna bila epidemija kuge iz 1739. Ta je epidemija pogodila osječki Donji grad, Cernik, Gradišku, a osobito teško grad Požegu i požešku dolinu. U gradu je Požegi od kuge umrlo $50 \%$ stanovništva, a u požeškoj dolini preko 1.300 ljudi. ${ }^{18}$ Kao spomen i zavjet za nedaće izazvane njome u Požegi je na središnjem trgu podignut barokni Kužni pil.

Ova je epidemija teško pogodila i osječki Gornji grad. U njemu je od 2.000 stanovnika umrlo $762 .{ }^{19}$

Godine 1795. u obližnjem Srijemu pojavila se kuga pa je uvedena karantena i čuvanje granice što je osječkim trgovcima prouzročilo znatne poteškoće. ${ }^{20}$ Epidemija je završila u proljeće 1796., ali je sanitarni kordon održan sve do početka srpnja iste godine kada je svečano zatvoren. ${ }^{21}$

Oprez vlasti i žitelja nije jenjavao pa slijedeće korake protiv kuge pronalazimo

14 Sršan, Slobodni i kraljevski grad Osijek 1809., 32.

15 Vidi, npr. "Kratki naputak kako se može čovek sačuvati od kratelja ili aziatičke kolere i kako treba postupati s bolestnikom prie neg lečnik prispie kad bi se njeni znakovi pojavili”, od 15. srpnja 1849., ili "Kratko ubavistjenje, kako se od istocsne zlatenice (cholere) scuvati more i shtose kod pervog nasertanja iste bolesti do doshastja jednog likara csiniti ima" od 10. srpnja 1831., HR-Državni arhiv Osijek, 6, kutija 5961.

16 von Taube, Slavonija i Srijem 1777.-1778., 131.-133.

17 „Najpouzdanija sredstva protiv zaraze su hladnokrvnost i odbacivanje svakog straha, potpuno uzdržavanje od jedenja mesa i puno pušenje duhana, tri protusredstva pomoću kojih mnogi Osmanlije ostaju potpuno zdravi.“

18 Skenderović, „Zdravstvene reforme Marije Terezije u Slavonskom provincijalu i Generale normativum sanitatis iz 1770.“, 165.

19 Božidar Plevnik, Stari Osijek, (Osijek, Radničko sveučilište Božidar Maslarić i I.C. Revija, 1987.), 93.

20 Stjepan Sršan, Osječki dnevnik Sebastiana Karla Redlsteina 1804.-1832., (Osijek, Državni arhiv Osijek; 1997.), 47.

21 Stjepan Sršan, Osječki ljetopisi, (Osijek, Državni arhiv Osijek; 1993.), 119-120. 
1814. i 1815. Godine 1814. kuga je izbila u Beogradu, a potom se proširila i na Bosnu. Kako je prijetila opasnost da se epidemija proširi i na područje austrijske carevine car je imenovao posebnog povjerenika koji je trebao „da uredi tako da se to zlo ne uvuče u našu dragu domovinu i da ne uzme maha kod nas". 22

Već 1815.. u Osijek je došao solarski službenik iz Stare Gradiške koji je prenoćio u Novoj Gradiški u kući u kojoj je nekoliko dana prije boravila osoba zaražena kugom. Kada se za to doznalo u karantenu je zatvoreno 11 kuća u osječkom Gornjem gradu i dvije u Donjem Gradu pod sumnjom da bi u njima moglo biti zaraženih osoba. ${ }^{23}$

Godine 1831. izbila je epidemija kolere. Stanovništvo i vlasti su do tada imale iskustvo s borbom protiv epidemija kuge i relativno su se dobro snašli i u dodiru s ovom bolešću. Epidemija kolere iz 1831. harala je velikim dijelom Carevine, izazvala je puno žrtava i veliki strah kod stanovništva. Stoga ne čudi da u ljetopisima osječkih samostana nailazimo na veliki broj upisa koji se odnose na nju.

Prvi zapis nalazimo već 18 . siječnja 1831. kada svećenici zapisuju da se bolest pojavila u Rusiji te da dnevno odnosi veliki broj života. Vlasti tada na granicu Galicije i Rusije postavljaju naoružane stražare, odnosno uvode sanitarni kordon, a odaslana su i dva posebna izaslanika koji su trebali poduzimati sve mjere da se bolest ne proširi u mađarski dio države.

Novi zapis koji se odnosio na epidemiju kolere potječe iz mjeseca veljače. Svećenici tada primjećuju da veliko siromaštvo i loši životni uvjeti u Rusiji pogoduju širenju kolere i velikoj smrtnosti. Također primjećuju da imućniji, koji se bolje hrane imaju veće šanse obraniti se od bolesti, odnosno ozdraviti. Znakovit je zapis koji i danas može biti aktualan. „Iz toga se vidi da je čistoća, dobra i zdrava hrana, redovito čišćenje zahoda i umjerenost najbolja mjera protiv spomenute bolesti."24

Fratri izvještavaju da je početkom mjeseca lipnja 1831. kolera počela harati u nekim mjestima Mađarske, a da je zbog opasnosti od kolere u kolovozu prestalo održavanje školske nastave.

U drugom osječkom, kapucinskom, ljetopisu, za epidemiju kolere iz 1831. pronalazimo da je u gradu Osijeku oboljelo 30 osoba. ${ }^{25}$

Austrijske vlasti poduzimale su određene mjere i radi sprječavanja širenja zaraze putem poštanskih pošiljki. Tridesetih godina 19. stoljeća u Europi se pojavila kolera, koja je iz Indije, preko Rusije i Galicije došla do granica Ugarske, pa su i poštanske pošiljke iz tih krajeva zahtijevale poseban postupak. ${ }^{26}$ Kako su iz zaraženih ili potencijalno zarazno opasnih krajeva u austrijsku carevinu dolazile poštanske pošiljke, postojala je mogućnost da se i putem njih unese zaraza. Stoga su sve poštanske pošiljke u Carevinu mogle ući samo na za to predviđenim mjestima. To nije bila osobita poteškoća zato što su, tzv. poštohodi, odnosno poštanske rute slijedile glavne prometnice kojima je u carevinu ionako ulazila većina robe. Na graničnim prijelazima nalazili su se kontumaci u kojima se obavljao i postupak s poštanskim

22 Sršan, Osječki ljetopisi, 136.

23 Sršan, Osječki ljetopisi, 137.

24 Sršan, Osječki ljetopisi, 146.

25 Sršan, Osječki ljetopisi, 334.

26 Andor Ber i Laszlo Makkai, Handbuch der ungarischen Vorphilatelie, (Budapest, Teka, 1990.), 83. 
pošiljkama.

Svako je pismo očišćeno na dva načina; ili je otvoreno i „očišćeno izvana i iznutra" ili je bušeno s velikim brojem rupica i dezinficirano parama. Nakon toga je dobivalo žig kojim je potvrđivano da je prošlo propisani postupak. ${ }^{27}$ Svaki kontumac, odnosno mjesto na kojem su pošiljke ulazile u austrijsku carevinu imao je svoj žig, koji su danas velika zanimljivost za kolekcionare. Na onodobnim pismima pohranjenim $\mathrm{u}$ hrvatskim arhivima nalazimo na razne žigove, npr; Geräuchert vom Contumaz zu Semlin, Netto di dentro e di fuora - Control amt Brood, Sanitatis sigilum, Von aussen und innen gereingt, Rein von innen und aussen i sl. ${ }^{28}$

I pisma koja su tijekom epidemije putovala unutrašnjim prometom prolazila su takav postupak kako se bolest ne bi proširila iz zaraženih u nezaražene krajeve. Ova je mjera kombinirana i s uvođenjem sanitarnih kordona unutar Carevine, a o čemu je već bilo riječi.

U ljetopisima osječkih samostana nalazi se puno zapisa koji su se odnosili na epidemije kuge, kolere i drugih bolesti, te na mjere koje su poduzimale državne, županijske i gradske vlasti u borbi protiv bolesti. Spomenut ćemo slučaj župnika u osječkoj Tvrđi, Antuna Josipa Turkovića, koji je u svoj dnevnik vrijedno zapisivao podatke o epidemiji kolere u Slavoniji 1806., sve dok od nje nije umro. Župnik je prvi zapis o koleri unio 1. veljače 1806., kada piše da su mnoga sela u Slavoniji zbog kolere zatvorena (stavljena u karantenu), te da dnevno samo u vojnoj bolnici umire od 20 do 30 osoba. Župnik je obolio 13 . veljače, a 13. ožujka je umro. ${ }^{29}$ Kratko vrijeme prije obolijevanja, početkom 1806., posvećivao je kuće u osječkoj Tvrđi. Posvetio je velik broj privatnih kuća, gostionica i vojnih objekata pa je vrlo lako moguće da se upravo tada zarazio kolerom.

U Osijeku je i 1830. harala epidemija boginja, a osobitost je da su ih dobivali i oni ljudi koji su ih preboljeli u djetinjstvu, te smrtnost kod većine oboljelih. ${ }^{30}$

\section{STANJE U JAVNOM ZDRAVSTVU U OSIJEKU I SLAVONIJI U DRUGOJ POLOVICI 19. STOLJEĆA}

Nakon ukidanja feudalizma polovinom 19. stoljeća u svakodnevni se pravni život počinje uvoditi niz zakona koji bitno drukčije reguliraju pravnu praksu. No, u ovlastima Slobodnog kraljevskog grada Osijeka malo se toga mijenja. Grad je i dalje ovlašten voditi brigu o stanju javnoga zdravstva na svome području. Car Franjo Josip I. posebnim carskim patentom od 7. rujna 1850. donosi Obćinski red za Kraljevski grad Ossek, a kojim se u paragrafu 79. propisuje da „Obćinsko veće uredjuje i ravna mestno zdravničtvo po obstojećih zakonih. ${ }^{\text {(31 }}$

$27 \mathrm{U}$ arhivskoj građi iz vremena epidemija kolere često se nalaze pisma na kojima se vide bušene rupice ili žigovi sanitarnih ureda.

28 Edwin Muellers, Handbook of the Pre-stamp Postmarks of Austria, (New York, Collectors Club, 1960.), 72.

29 Sršan, Osječki ljetopisi, 296.

30 Sršan, Osječki dnevnik Sebastiana Karla Redlsteina 1804.-1832., 98.

31 Carski patent od 7. rujna 1850. kojim se odobrava i u kriepost stavlja privremeni obćinski red za kraljevski grad Ossek, Gedruckt bei Diwald in Essegg. 
U slijedećih dvadesetak godina Hrvatska i Slavonija postupno ulaze u građanski sustav društva i polako raskidaju veze s feudalnim. Na tome je putu bilo više pokušaja reformi. Neke od njih nisu uspijevale, vraćalo se na stare oblike uprave i tražio se najučinkovitiji način.

Nove su mogućnosti na reformskom putu otvorene i sklapanjem Hrvatskougarske nagodbe 1868. kojom velik broj ovlasti u upravi i sudstvu prelazi u autonomnu nadležnost Hrvatske, a između ostalih i uređivanje javnog zdravstva.

To je otvorilo put novim velikim promjenama u zakonodavnom uređivanju pitanja javnoga zdravstva tijekom banovanja Ivana Mažuranića osamdesetih godina 19. stoljeća Tada se pristupa velikim reformama na mnogim područjima javnoga života, pa tako i zdravstva.

Prvi je korak na tome putu bio donošenje Zakona o uređenju zdravstva $u$ Hrvatskoj i Slavoniji, a potom i niza propisa kojima se podrobnije uređuju pojedina pitanja iz područja javnoga zdravstva.

Zakonom o uređenju zdravstva u Hrvatskoj i Slavoniji iz 1874. podrobno su propisane nadležnosti i djelatnosti na području javnoga zdravstva. ${ }^{32}$

Kao vrhovno tijelo za brigu o javnom zdravstvu na području Hrvatske i Slavonije određena je Kraljevska hrvatsko-slavonsko-dalmatinska zemaljska vlada.

$\mathrm{Na}$ nižim razinama brigu o provođenju Zakona i odluka Vlade obavljale su političke oblasti i to podžupanije i gradovi, odnosno općine s imenovanim magistratom. U tu su svrhu u podžupanijama imenovani podžupanijski liječnici i živinari a u gradovima posebna tijela nadležna za zdravstvo koje su imenovali gradski zastupnici.

Pojedine političke općine su radi obavljanja djelatnosti iz djelokruga javnog zdravstva poduzimale niz djelatnosti; provodile propise o cestama, ulicama, putovima, tržnicama, trgovima, kanalima, zahodima, tekućim i stojećim vodama, javnim kupalištima i dr. Brinule su, o bolesnicima, porođajima i nesrećama. Vodile su evidenciju o gluhonijemima i osobama s psihičkim smetnjama koje su se nalazile u zavodima. Organizirale su i održavale mrtvačnice i groblja, te vodile brigu o očevidu mrtvaca. Također su vodile brigu o zdravstvenoj ispravnosti klaonica, te nadzoru nad stočnim sajmovima.

Političke općine su također $\mathrm{u}$, tzv. prenesenom djelokrugu poslova obavljale i druge zdravstveno redarstvene i zdravstveno upravne poslove koje im je povjerila Vlada.

Podžupanijski liječnici na području svake podžupanije obavljali su niz dužnosti na provođenju mjera za zaštitu javnoga zdravstva. Tako su, primjerice, nadzirali zdravstvo i zdravstveno osoblje zaposleno u državnoj, općinskoj, ali i privatnoj službi na području podžupanije, izvršavanje zdravstvenih propisa, kao i propisa o nadriliječništvu, te promet otrovima i lijekovima, nadzirali su rad kupališta i provođenje cijepljenja protiv boginja, provodili zdravstveno-redarstveni nadzor nad bolnicama, primjenjivali mjere za ograničavanje i suzbijanje ljudskih i stočnih zaraznih bolesti i dr.

Odredbama ovoga Zakona propisano je da se osim navedenoga zdravstvenog osoblja na području svake upravne oblasti treba zaposliti potreban broj diplomiranih

32 Sbornik zakonah i naredabah valjanih za kraljevine Hrvatsku i Slavoniju, br. 435., 1874. 
primalja sa položenim ispitom.

Imenovano je i Zemaljsko zdravstveno vijeće koje je bilo vladino savjetodavno tijelo u svim poslovima povezanim sa zdravstvom. Vijeće je bilo sastavljeno od redovitih članova: vladinog izvjestitelja u zdravstvenim poslovima, zemaljskoga veterinara i najmanje četiri liječnika, te izvanrednih članova koji su se imenovali po potrebi ovisno o slučaju. Redoviti su članovi imenovani na tri godine.

Osim ovoga temeljnog zakona donesen je još i niz naputaka i odredbi kojima su podrobnije uređena pojedina područja javnoga zdravstva, te je time izgrađena uistinu učinkovita mreža propisa koji su regulirali to područje. Među važnijima su: Naputak za podžupanijske liečnike i za gradske fizike, ${ }^{33}$ Naredba proti prekomjernom pušćanju krvi, Zakon o ustroju primaljskog učilišta u Zagrebu, Naredba o primanju nosećih ženskijah na radjanje kod primaljah, Naputak za živinare, Red za zborove liekarske, Propis o domaćih liekarnah. Naredba u pogledu liekovnog cienika, Naredba o rukovanju i trgovini sa otrovi, Naredba o razgledbi mesa, Naredba o kvarenju i patvorenju pića, Naredba o ciepljenju proti boginjah, Naputak kako treba da se postupa prigodom vladajuće medju pučanstvom pošasti u obće a kolere napose, Naredba o javnoj opskrbi siromaha u njihovoj općini ali i u javnim ubožnicama $i$ zdravstvenim zavodima, Naredba o reguliranju djelatnosti kupališta, Opskrba bolesnika u zemaljskoj ludnici, Naredba o ogledu mrtvaca, Pravilnik o transportu mrtvaca, Naredba o uređenju rakah (grobova) i groblja, Zakon o postupku protiv goveđe kuge, Okružnica o postupku protiv stočnih pošasti i dr. ${ }^{34}$

Godine 1894. donosi se novi zakon o uređenju zdravstvene službe u Kraljevinama Hrvatskoj i Slavoniji. ${ }^{35}$ Nakon dvadeset godina primjene zakona iz 1874. pokazala se potreba za donošenje novoga zakona. Ne toliko radi nedostataka staroga ili uvođenja nekih velikih novina, već radi usklađivanja s teritorijalnim i upravnim promjenama koje su u međuvremenu provedene.

Naime, došlo je do reintegracije Vojne krajine i do važnih reformi u upravnom sustavu, pa je novim zakonom stanje u javnom zdravstvu usklađeno s upravnim sustavom u Hrvatskoj i Slavoniji.

Tako je prema odredbama ovoga zakona za upravljanje i nadzor nad svim poslovima javnoga zdravstva na području Kraljevina Hrvatske i Slavonije, također nadležna Zemaljska vlada. U sklopu Vlade za provođenje tih poslova postojali su poseban zdravstveni odsjek i zemaljsko zdravstveno vijeće. ${ }^{36}$

Na područjima županija i gradova ${ }^{37}$ te su poslove obavljali županijski fizici i županijski zdravstveni odbori, odnosni gradski liječnici, gradski zdravstveni odbori i

33 Vidi kod Milivoj Vežić, Pomoćnik za javnu upravu, (Zagreb, Naklada Akademijske knjižare L. Hartmana,, 1884.), 314 i dalje.

34 Vežić, Pomoćnik za javnu upravu, 320-579.

35 Sbornik zakonah i naredabah valjanih za kraljevine Hrvatsku i Slavoniju, komad IV., broj 9., 1894.

36 Marinko Učur, Željko Bartulović, Sandra Debeljak, „Pravna regulativa kriznih situacijau 18. i 19. stoljeću, de lege lata i nomotehničke pretpostavke za izradu propisa de lege ferenda u Republici Hrvatskoj“, International Conference on Innovative Technologies in Safety Engineering, v 1., 111.

37 I na području trgovišta Rume. 
gradske primalje, a kod kotarskih oblasti kotarski liječnici. ${ }^{38}$

Glavna je namjera zakonodavca bila da se uvođenjem županijskih i gradskih zdravstvenih odbora zapravo uvaže činjenice o konkretnom stanju na terenu, odnosno u pojedinoj županiji i gradu te da se time bolje i učinkovitije provode mjere državnih vlasti o skrbi za javno zdravstvo. ${ }^{39}$

Propisano je i da se u gradovima do 5.000 stanovnika treba imenovati jedan liječnik, do 10.000 dva, do 20.000 tri, a preko 20.000 za svakih daljih 10.000 stanovnika po jedan liječnik. ${ }^{40}$

Osobita se briga i dalje vodila o suzbijanju zaraznih bolesti, pa u slučaju njihove pojave županijski i gradski zdravstveni odbori postaju, tzv. pošastni odbori koji imaju sve ovlasti u suzbijanju epidemije.

Nakon ovoga Zakona donesen je i niz drugih propisa koji su podrobnije regulirali mjere i postupke u sprječavanju prodora različitih zaraznih bolesti, odnosno postupke u slučaju izbijanja epidemija. Između ostalog osobita se pažnja posvećivala borbi protiv prodora kolere, kuge, boginja, bjesnila, bludoboli (spolnih bolesti), tuberkuloze, difterije i dr. ${ }^{41}$

Kao važna djelatnost u sklopu skrbi o javnom zdravstvu pokazala se i veterinarska struka. Česte su bile epidemije stočnih bolesti (osobito goveđe kuge) koje su izazivale ogromne ekonomske štete i država je vrlo ozbiljno pristupala suzbijanju epidemija i reguliranju veterinarske službe. Zakon o uređenju zdravstva iz 1874. godine veterinarsku struku je tretirao kao usputnu zdravstvenu struku i nije je dostatno podrobno regulirao. Došlo je i do već spomenutih teritorijalnih i upravnih promjena u Kraljevinama Hrvatskoj i Slavoniji, pa je stanje u veterinarskoj struci trebalo uskladiti sa stvarnim stanjem i regulirati na bolji, moderniji i učinkovitiji način. Uz to i Ugarska je donijela novi veterinarski zakon koji je bio usklađen s austrijskim te uveden i na područje Bosne, tako da je donošenje novoga zakona koji bi regulirao veterinarsku službu i u Hrvatskoj i Slavoniji bila nužnost. ${ }^{42}$

Stoga se 1888. donosi novi Zakon o uređenju veterinarstva i prateći propisi koji iscrpno uređuju postupanja u slučajevima, tzv. ,marvinskih pošasti.“43

Ovim je zakonima i propisima je u Hrvatsku i Slavoniju uveden za ono vrijeme napredan sustav zakonske regulative i brige o javnom zdravstvu koji je ostao na snazi sve do raspada Austro-Ugarske Monarhije. Manjih je promjena doduše bilo, ali one nisu zadirale u bit uspostavljenoga sustava javnog zdravstva.

Osobit doprinos zakona iz 1874. i 1894. bio je što je u Hrvatskoj uveden moderan sustav javnog zdravstva, koji je usklađen sa upravnim sustavom. Takav je sustav omogućavao da se na području Hrvatske i Slavonije učinkovito vodi briga o

38 Milivoj Smrekar, Priručnik za političku upravnu službu, knj. 1, (Zagreb, tiskom Ignjata Granitza 1899.), 178.

39 Smrekar, Priručnik za političku upravnu službu, knj. 1, 179.

40 Smrekar, Priručnik za političku upravnu službu, knj. 1, 183.

41 Učur, Bartulović, „Zaštita od „pošasti“ u hrvatskoj povijesti u 18. i 19. stoljeću i nomotehničke pretpostavke za izradu propisa de lege ferenda“, str. 524.

42 Smrekar, Priručnik za političku upravnu službu, knj. 1, 214-215.

43 Učur, Bartulović, Zaštita od „pošasti “ u hrvatskoj povijesti u 18. i 19. stoljeću i nomotehničke pretpostavke za izradu propisa de lege ferenda, 525. 
svim segmentima javnoga zdravstva a koji je svoj oslonac nalazio u snažnom i dobro uhodanom upravnom sustavu i upravnim tijelima.

Nužno je istaknuti da se osobita briga posvećivala zaštiti i prevenciji od zaraznih bolesti (pošasti) kod ljudi, osobito kuge, kolere i boginja, a tako i stočnih, osobito goveđe kuge, koje su se zbog toga pojavljivale sve rjeđe. ${ }^{44}$

\section{ZAKLJUČAK}

Iz iznesenog vidimo da su skrb za javno zdravstvo podržavale sve vlasti u Slavoniji od oslobođenja od Turaka pa do 1918. U prvoj polovici 18. stoljeća briga o javnom zdravstvu bila je u nadležnosti vojnih vlasti, a provodili su je najviše vojni liječnici. Nakon uvođenja županija na dijelu teritorija Slavonije, u vrijeme carice Marije Terezije, nadležnost u provođenju mjera za očuvanje javnoga zdravlja prelazi u djelokrug civilnih, županijskih, a od dobivanja statusa slobodnog kraljevskog grada 1809. u Osijeku, u nadležnost gradskih vlasti.

Pritom su gradske odnosno županijske vlasti zapravo bile samo provoditelji odluka, odnosno naredbi i propisa državnih vlasti, na nižoj razini. U toj funkciji županijske i gradske vlasti su „na terenu“ uvele učinkovitu mrežu osoblja koje se brinulo o javnom zdravstvu; gradskih i županijskih zdravstvenih odbora, liječnika, primalja i dr. koji su se učinkovito brinuli o zaštiti javnog zdravlja stanovništva.

Posebnost Slavonije bila je u tome što se nalazila na granici austrijske carevine prema turskom carstvu u kojemu su često vladale epidemije raznih bolesti i zato se posvećivala velika pažnja borbi protiv prodora i izbijanja epidemija.

Efikasnost vlasti u carevini, i vojnih, i županijskih i gradskih pokazuje i činjenica da je najstrašnija onodobna bolest, kuga uspjela prodrijeti samo dva puta, 1739. i 1795. Epidemija drugih zaraznih bolesti bilo je više, ali su dobrom primjenom uputa središnjih vlasti i učinkovitim radom županijskih i gradskih tijela brzo suzbijane.

\section{LITERATURA}

1. Ber, Andor i Laszlo Makkai. Handbuch der ungarischen Vorphilatelie. Budapest: Teka, 1990.

2. Braudel Fernand. Strukture svakidašnjice, Materijalna civilizacija, ekonomija $i$ kapitalizam od XV., do XIII. stoljeća. Zagreb: August Cesarec, 1992.

3. Carski patent od 7. rujna 1850. kojim se odobrava i u kriepost stavlja privremeni obćinski red za kraljevski grad Ossek. Gedruckt bei Diwald in Essegg, 1850.

4. Goricke-Lukić, Hermina. Nekropole rimsko dobne Murse. Osijek: Muzej Slavonije, 2011

5. Grmek, Mirko Dražen. Bolesti u osvit zapadne civilizacije. Zagreb: Globus, 1989.

6. Kratki naputak kako se može čovek sačuvati od kratelja ili aziatičke kolere i kako treba postupati s bolestnikom prie neg lečnik prispie kad bi se njeni znakovi pojavili, od 15.

$44 \mathrm{U}$ arhivskim fondovima iz druge polovine 19. stoljeća pronalazi se veliki broj naredbi i naputaka kako se treba postupati kod izbijanja zaraza, npr. Naredba Zemaljske vlade od 31. X 1895., br. 57.220 o tamanjenju svinjske pošasti, ili Naputak o kratelju-koleri, br. 36878/1886., ili Pouka o koleri i mjerah proti njoj, ili Naredba Zemaljske vlade od 19. VII. 1893., br. 34.839 o postupku proti pogibelji kolere, iz fonda Poglavarstvo slobodnog i kraljevskog grada Karlovca 1850.1918., HR-Državni arhiv Karlovac, 0002. 
srpnja 1849. HR-Državni arhiv Osijek, kutija 5961.

7. Kratko ubavistjenje, kako se od istocsne zlatenice (cholere) scuvati more $i$ shtose kod pervog nasertanja iste bolesti do doshastja jednog likara csiniti ima od 10. srpnja 1831. HR-Državni arhiv Osijek - 6, kutija 5961.

8. Le Goff, Jacques. Civilizacija srednjovjekovnog zapada. Zagreb: Golden Marketing, 1998.

9. Nikolaj A. Maškin, Istorija starog Rima, Beograd, IDP Naučna KMD, 2005.

10. Muellers, Edwin. Handbook of the Pre-stamp Postmarks of Austria. New York: Collectors Club, 1960.

11. Naputak o kratelju-koleri, br. 36878/1886. HR-Državni arhiv Karlovac, 0002.

12. Naredba Zemaljske vlade od 19. VII. 1893., br. 34.839 o postupku proti pogibelji kolere, Poglavarstvo slobodnog i kraljevskog grada Karlovca 1850.-1918. HR-Državni arhiv Karlovac, 0002.

13. Naredba Zemaljske vlade od 31. X 1895., br. 57.220 o tamanjenju svinjske pošasti. HRDržavni arhiv Karlovac, 0002.

14. Plevnik, Božidar. Stari Osijek. Osijek: Radničko sveučilište Božidar Maslarić i I.C. Revija, 1987.

15. Pouka o koleri i mjerah proti njoj. HR-Državni arhiv Karlovac, 0002.

16. Rabar, Ivan, Poviest carstva rimskoga, Zagreb, Naklada Matice hrvatske, 1888.

17. Sbornik zakonah i naredabah valjanih za kraljevine Hrvatsku i Slavoniju br. 435. (1874.).

18. Sbornik zakonah i naredabah valjanih za kraljevine Hrvatsku i Slavoniju br. 9 (1894.).

19. Smrekar Milan. Priručnik za političku upravnu službu. knj. I., Zagreb: tiskom i nakladom Ignjata Granitza, 1899.

20. Sršan, Stjepan. Osječki dnevnik Sebastiana Karla Redlsteina 1804.-1832. Osijek: Državni arhiv Osijek, 1997.

21. Sršan, Stjepan. Osječki ljetopisi. Osijek: Državni arhiv Osijek, 1993.

22. Sršan Stjepan. Slobodni i kraljevski grad Osijek 1809. Osijek: Državni arhiv Osijek, 2009.

23. Skenderović Robert. „Zdravstvene reforme Marije Terezije u Slavonskom provincijalu i Generale normativum sanitatis iz 1770.“, Scrinia Slavonica br. 5 (2005.), 115-143.

24. Učur, Marinko, Željko Bartulović, „Zaštita od „pošasti“ u hrvatskoj povijesti u 18. i 19. stoljeću i nomotehničke pretpostavke za izradu propisa de lege ferenda“, u: Zbornik radova sa III međunarodnog naučnog skupa Katastrofe prevencija i saniranje posljedica, ur. Mirko Kulić, I tom, Brčko, 2015., 521-531.

25. Učur, Marinko, Željko Bartulović, Sandra Debeljak, "Pravna regulativa kriznih situacija u 18. i 19. stoljeću, de lege lata i nomotehničke pretpostavke za izradu propisa de lege ferenda u Republici Hrvatskoj“, International Conference on Innovative Technologies in Safety Engineering, ur. Dario Bognolo i dr.,Poreč: Quimedia, no 11 (2015.), 109-122.

26. Vežić Milivoj. Pomoćnik za javnu upravu. Zagreb: Knjižara Hartman, 1884.

27. von Taube, Friedrich Wilhelm. Slavonija i Srijem 1777.-1778. Osijek: Državni arhiv Osijek, 2012.

28. Wiewegh, Zoran. Jugoistočna nekropola Siscije. Sisak: Gradski muzej Sisak, 2003. 


\author{
Miro Gardaš* \\ Slavko Čandrlić** \\ Marko Repić***
}

Summary

\title{
AUTHORITIES AND MEASURES OF COUNTY AND CITY AUTHORITIES IN PUBLIC HEALTH IN SLAVONIA IN THE 19 $^{\text {TH }}$ CENTURY
}

\begin{abstract}
During the $19^{\text {th }}$ century, there was a constant risk of outbreaks of infectious diseases in Slavonia. Therefore, the counties and city authorities had a duty to take care to prevent them. In implementing these measures, they took care of the implementation of the instructions sent to them by the central state authorities, many of which are preserved in the archives of the various funds kept in the State Archives in Osijek.

At the beginning of the $19^{\text {th }}$ century, Osijek was granted the status of a free royal city, and it was within its competence to implement measures to prevent epidemics, for which unique bodies were set up in the city administration. After the abolition of feudalism, and especially during the time of Ban Ivan Mažuranić, began significant reforms of the public health system. The Public Health Act of 1874 was adopted, and several accompanying regulations were addressing this issue. A new law was enacted in 1894, which introduced certain newspapers, mostly to bring it into line with the new territorial organization. Regulated health care provided a useful framework for adequate public health protection and epidemic prevention.
\end{abstract}

Keywords: history; law; Slavonia; $19^{\text {th }}$ century; public health.

* Miro Gardaš, Ph.D., Full Professor, Faculty of Law, Josip Juraj Strossmayer University of Osijek; mgardas@pravos.hr.

** Slavko Čandrlić, Mag. iur. Ph.D., Student, Faculty of Law, Josip Juraj Strossmayer University of Osijek; slavko.candrlic@fdmz.hr.

*** Marko Repić, Student, Faculty of Law, Josip Juraj Strossmayer University of Osijek; mrepic@ hotmail.com. 
Zusammenfassung

\section{BEFUGNISSE UND MASSNAHMEN DER GESPANSCHAFTS- UND STADTGEWALT IM GESUNDHEITSWESEN SLAWONIENS IM 19. JAHRHUNDERT}

Im 19. Jahrhundert stand Slawonien ständig in Gefahr vor Ausbruch von Infektionskrankheiten. Sowohl Gespanschafts- als auch Stadtgremien waren verpflichtet entsprechende Präventionsmaßnahmen zu treffen. Dabei mussten diese Gremien in Einklang mit Leitsätzen der zentralen Staatsgewalt handeln, von denen viele im Staatsarchiv Osijeks aufbewahrt wurden.

Anfang des 19. Jahrhunderts wurde Osijek der Status einer freien königlichen Stadt erteilt. Als Folge dessen, hatte die Stadt auch Zuständigkeit über Durchführung von Maßnahmen zur Epidemieprävention und zu dem Zweck wurden Sondergremien in der Stadtverwaltung aufgebaut. Nach dem Ende des Feudalismus, und insbesondere zur Zeit des Feldherrn und Bans Ivan Mažuranić, wurden tiefgreifende Reformen des öffentlichen Gesundheitswesens ergriffen. Das Gesetz über öffentliches Gesundheitswesen und verwandte Vorschriften wurden 1874 verabschiedet. Ein neues Gesetz, welches gewisse Neuigkeiten umfasste, wurde 1894 wegen Anpassung an den neuen territorialen Aufbau verabschiedet. Ein solches Gesundheitswesen stellte einen soliden Rahmen für wirkungsvollen Gesundheitsschutz der Bevölkerung und Prävention von Epidemien.

Schlüsselwörter: Geschichte; Recht; Slawonien; 19. Jahrhundert; öffentliches Gesundheitswesen.

Riassunto

\section{POTERI E MISURE DELLE AUTORITÀ DELLE CONTEE E DELLE CITTÀ NELLA SANITÀ PUBBLICA IN SLAVONIA NEL XIX SECOLO}

Durante il XIX secolo in Slavonia si visse continuamente in una situazione di pericolo che scoppiasse un'epidemia di malattie infettive. Pertanto le autorità delle contee e delle città ebbero l'obbligo di premurarsi di intraprendere misure per prevenirle. Nell'esecuzione di queste misure ponevano in atto le istruzioni che arrivavano dalle autorità statali centrali. Numerosi esempi di tali istruzioni sono rimasti conservati negli archivi storici di diversi fondi custoditi nell'Archivio statale di Osijek.

Osijek all'inizio del XIX secolo ottenne lo status di città reale libera e tra le 
sue competenze venne inserito anche intraprendimento di misure per la prevenzione dell'epidemia per la quale sono stati istruiti organi speciali nell'amministrazione cittadina. Dopo l'abolizione del feudalismo, particolarmente nell'epoca del bano Ivan Mažuranić, si intrapresero vaste riforme del sistema della sanità pubblica. Si adottò la Legge sulla sanità pubblica nel 1874 ed una serie di regolamenti allegati, che trattavano questa problematica. La nuova legge che introdusse alcune novità si adottò nel 1894, soprattutto per armonizzarla con la nuova organizzazione territoriale. La sanità regolata in questo modo offrì un buon quadro normativo per una protezione sanitaria efficace e per la prevenzione dello scoppio dell'epidemia.

Parole chiave: storia; diritto; Slavonia; XIX secolo; Sanità pubblica. 
